\title{
Destinasyonlara İlişkin Hatırlanabilir Deneyimlerin Turistlerin Tekrar Seyahat Niyetlerine Etkileri: Side Örneği
}

\author{
Dr. Öğr. Üyesi Aydın ÜNAL \\ Kırklareli Üniversitesi Pınarhisar Meslek Yüksekokulu Kırklareli \\ aydin.unal@klu.edu.tr \\ https://orcid.org/0000-0002-6377-8587 \\ Yüksek Lisans Öğrencisi Sinan Baran BAYAR \\ Kurklareli Üniversitesi Sosyal Bilimler Enstitüsü \\ sinanbbayar@gmail.com \\ https://orcid.org/0000-0002-3039-3162 \\ https://doi.org/10.37847/tdtad.715848
}

\section{Özet}

Destinasyonlar arası rekabet avantaj1 sağlamada turistlerin hatırlanabilir deneyimleri en az destinasyonların sundukları turistik çekicilikleri, hizmet kalitesi ve eşsizlikleri kadar önemli bir unsur olarak öne çıkmaktadır. Çünkü turistlerin destinasyonlara yönelik önceki seyahatleri ile ilgili olumlu veya olumsuz hatıraları sonraki destinasyon ve seyahat tercihlerine doğrudan etki etmektedir. Bu kapsamda çalışmada Side destinasyonunu Mayıs-Eylül 2019 döneminde ziyaret eden yerli turistlerin seyahat niyetlerine destinasyon hatırlanabilir deneyim boyutlarının etkilerinin belirlenmesi amaçlanmaktadır. Bu kapsamda hazırlanan 500 anket formu yerli turistlere yüz yüze iletişim kurularak ulaştırılmıştır. Anketlerden elde edilen veriler (456 anket) SPSS programında analize tabi tutulmuştur. Yapılan analizler sonucunda yerli turistlerin önceki seyahat deneyimlerinden çok yüksek düzeyde etkilendikleri (\%75) ve Side destinasyonuna tekrar seyahat etme niyetinde oldukları (\%83) belirlenmiştir. Yerli turistlerin destinasyon hatırlanabilir deneyimlerinin hedonizm, yenilik, bilgi, anlamlılık, katılım, yerel kültür ve ferahlık boyutlarından oluştukları sonucuna ulaşılmıştır. Ayrıca tüm destinasyon hatırlanabilir deneyim boyutlarının turistlerin destinasyon tekrar seyahat niyetlerini yüksek ve olumlu düzeyde etkilediği sonucuna da ulaşılmıştır.

Anahtar Kelimeler: Destinasyon Pazarlamas1, Hatırlanabilir Deneyim, Tekrar Seyahat Niyeti, Yerli Turist, Side.

\section{Effects of Memorable Experiences Regarding Destinations on Tourists' Revisit Intentions: The Case of Side}

\begin{abstract}
Tourists' memorable experiences stand out as important as the tourist attractions, quality of services and uniquenesses of destinations in destinations' providing competitive advantage between each other. Because the positive or negative memories of the tourists about their previous travels to the destinations directly affect their next destination and travel preferences. In this context, this study aims to determine the effects of destination memorable experience dimensions on the revisit intentions of domestic tourists who visited Side destination in the period of May-September 2019. 500 questionnaire forms prepared within this scope were delivered to the domestic tourists by face-
\end{abstract}


to-face communication. The data obtained from the questionnaires (456 questionnaires) were analyzed by use of the SPSS program. As a result of the analyzes, it was determined that the domestic tourists were highly affected by their previous travel experiences $(75 \%)$ and that they intended to travel to Side again $(83 \%)$. It was concluded that the domestic tourists' destination memorable experiences consisted of dimensions of hedonism, innovation, knowledge, significance, participation, local culture and refreshment. In addition, it was concluded that all of the memorable experience dimensions regarding Side affected the destination revisit intentions of the tourists at a high and positive level.

Keywords: Destination Marketing, Memorable Experience, Revisit Intention, Domestic Tourist, Side.

\section{Giriş}

Turistlerin tatilleri esnasında edindikleri olumlu ve olumsuz deneyimleri turizm endüstrisinin ve destinasyon pazarlamasının temelini oluşturan önemli unsurlardandır. Deneyim; tüketiciler açısından ekonomik temelli bir tüketim davranışı olmaktan öteye duygusal ve sürekli olarak güncellenen çok bileşenli bir kavramdır (Akkuş, 2017, 224). Turizm temelli deneyim ise turistlerin tercih ettikleri destinasyonlarla ilgili paylaştıkları tüm etkileşimleri kapsayan bir kavramı ifade etmektedir (Demir ve Demirel Ülker, 2019, 662). Turizm temelli deneyim sadece destinasyonlarda satın alınan veya tüketilen somut ürünlerden ve yerinde tüketilen hizmetlerden ibaret değildir. Aynı zamana hatırlanabilir duygusal anları da içinde barındırmaktadır (Cornelisse, 2014, 104).

Turistlerin mevcut birçok destinasyon arasından nereye gideceğine karar verme sürecinin başlangıcından seyahat planının içeriğine kadar sürecin bütününde biriktirilebilir ve hatırlanabilir turizm deneyimleri belirleyici olmaktadır (Duarte, 2012, 187). Turistik hatırlanabilir deneyimler turistlerin aynı destinasyona yeniden seyahat etmesinde ve ağızdan ağza iletişimlerinde önemli bilgi kaynaklarıdır (Marschall, 2012, 2217). Ayrıca turistlere benzersiz, olağanüstü ve hatırlanabilir anları barındıran hatırlanabilir turizm deneyimleri sunan bir destinasyon turistlerin tekrar ziyaret niyetlerini ve destinasyonu tavsiye kararlarını doğrudan ve güçlü bir biçimde etkilemektedir (Han ve diğerleri, 2009, 564; Kim, 2010, 783; Chen ve Rahman, 2018, 155; Zhang ve diğerleri, 2017, 327). Geçmiş deneyimlerine dayanarak önyargılı seçimler yapma eğilimde olabilen turistler seyahat etmeye ve belirli destinasyonlar hakkında bilgi araştırmaya karar verirken geçmiş deneyimlerini hatırlayabilirler (Kerstetter ve Cho, 2004, 964). Turistler açısından hatırlanabilir deneyimler; geçmiş deneyimler çerçevesinde ele alındığında ürün katılımı ve ürünü satın alma motivasyonu daha yüksek olduğu için, tüketiciler geçmiş deneyimleri değerli ve güvenilir bilgi kaynakları olarak gördükleri için ve geçmiş deneyimlerin gelecekteki karar verme süreçlerine büyük bir etkisi olduğu için önem arz etmektedir (Hoch ve Deighton, 1989, 4).

Hatırlanabilir turizm deneyimleri ile yapılmış çalışmalarda çoğunlukla yedi boyut üzerinde durulmaktadır (Kim ve diğerleri, 2012, 14). Bu boyutlardan hedonizm; Yunanca "Hedone" kavramından türetilmiş bu kavram zevk alma, keyif ve uyarılma anlamları taşımaktadır. Keyif ve zevk hissi turistlerin boş zaman deneyimlerinin ayrılmaz bir parçasıdır (Sthapit, 2013, 37) ve turistlerin memnuniyetini ve gelecekteki davranışlarını belirlemede önemli bir bileşendir (Dunman ve Mattila, 2005, 315). Ferahlık boyutu; Kim ve diğerleri (2010) ferahlamanın ve ferahlık hissinin turistlerin seyahat anılarını etkilediğini belirtmektedir. Bowen ve Clarke (2009) turistlerin destinasyonda geçirdikleri zamanın "özgür” olarak algılamasının turistlerin deneyimi için önemli olduğunu belirtmektedirler. Ayrıca tatmin edici deneyimler biriktirilmesi sonucunda turistlerin 
hayatta karşılaşabilecekleri stres ve psikolojik sorunlar ortadan kalkmaktadır ve turistler daha istikrarlı bir ruh haline kavuşmaktadırlar (Uysal ve diğerleri, 2012, 264). Yerel kültür boyutu; turizm deneyimleri turistleri tercih ettikleri destinasyonda yaşayan yerel halk ile iletişimini barındırır ve etkileşimini gerekli kılmaktadır (Ooi, 2003, 35). Destinasyonlarda turistlerin deneyimlerine sürekli olarak sosyal etkileşimler ve sosyal ilişkiler aracilık ederler (Selstad, 2007: 24). Hatırlanabilir destinasyon deneyimleri içerisinde yerel halkla etkileşim halinde olan turistlerin geçmiş deneyimlerini yüksek düzeyde hatırladıkları tespit edilmiştir (Kim ve diğerleri, 2010, 786). Anlamlılık boyutu; turistler bir turizm destinasyonunu yalnızca manzarası, yerel halk1 ve diğer turistik çekicilikleri çerçevesinde tüketmekten ziyade kişisel gelişim ve içsel bir yolculuk deneyimlemek için tercih edebilmektedirler (Kim, 2014, 36). Bu sayede fiziksel deneyimlerin yanı sıra seyahatten bilişsel faydaların elde edilmesi de sağlanabilmektedir. Bilgi boyutu; turistlere satın alma karar sürecinde oldukları veya tercih ettikleri destinasyonla ilgili bilgilendirmeyi, öğrenme firsatları sunmayı ve keşfetmeyi ve anlama dürtüsü kazandırmayı ifade etmektedir. Ziyaret edilecek destinasyon hakkında coğrafi, doğal, fiziki ve tarihi konularda bilgi sahibi olmak turistlerin karşılaşabilecekleri riskleri ve tehlikelerin minimize edilmesine katk1 sunmaktadır (Sthapit, 2013, 37). Katılım boyutu; turistlerin kişisel gereksinimlerine, değerlerine, inançlarına ve ilgi alanlarına bağlı kalarak kendilerine en yakın gördükleri destinasyona eğilimlerini ve deneyimlerini ifade etmektedir (Kutlu, 2019, 76).

Turistik faaliyetlerde ve destinasyon seçim süreçlerinde potansiyel turistlerin aşinalık arama arzuları rutinden uzaklaşma arzuları kadar önem arz etmektedir. Yenilik boyutu ise turistler arzularını ve isteklerini tatmin etmek için farklı destinasyonları seçmek, yeni şeyler denemek, rutinden uzaklaşmak ve kendi ülkelerinde bulunamayan bir ürüne ulaşmayı deneyimlemek isterler (Kim, 2014, 36). Bu sayede bilgi düzeylerini arttırma, sosyal çevrelerini genişletme, yeni kültürleri tanıma ve özellikle sosyal mecralarda takip edilme, vb. hususlarda elde edecekleri deneyimler ve kazanımlar artabilmektedir.

$\mathrm{Bu}$ çalışmada Side destinasyonunu ziyaret eden yerli turistlerin destinasyon seyahat niyetlerine destinasyon hatırlanabilir deneyim boyutlarının etkilerinin belirlenmesi amaçlanmaktadır. Çalıșmanın konusu ve ölçeği itibariyle ilgili alanyazında birçok çalıșmaya konu edilse de Side destinasyonu özelinde konuyu ele alan bir çalıșmaya ulașılmamıștır. Bu nedenle çalıșmanın uygulama temelli sonuçları itibarıyla bașta Side destinasyonu olmak üzere diğer destinasyon yönetim ve pazarlama örgütlerine önemli katkılar sağlayacağı düşünülmektedir. Araştırma kapsamında oluşturulan Destinasyon Hatırlanabilir Deneyim (DHD) ve Destinasyon Seyahat Niyeti (DSN) modeli ve elde edilen sonuçlar kapsamında turistlerin destinasyon seyahat niyetlerine destinasyon hatırlanabilir deneyim boyutlarının ne düzeyde etki edebileceği ve bu süreçte etkili olan boyutların daha net analiz edilebileceği düşünülmektedir. Bu çerçevede çalışmada öncelikle araştırmanın kuramsal çerçevesi oluşturulmuştur ve konu ile ilgili yapılmış diğer çalışmalar özetlenmiştir. Daha sonra araştırma yöntemi tasarlanmıştır, araştırma modeli ve ilgili araștırma hipotezleri çerçevesinde gerekli analizler uygulanmıştır ve araştırma bulgularına ulaşılmıştır. Araştırma da son olarak araştırma bulguları kısaca özetlenerek sonuç ve tartışma bölümü oluşturulmuştur.

\section{İlgili Araştırmalar}

Kim ve diğerleri (2012) Churchill'in (1979) çalışmasını referans alarak hazcılık, ferahlık, yerel kültür, anlamlılık, bilgi, katılım ve yenilik faktörlerini içeren ölçeğin hatırlanabilir deneyime etkilerini belirlemek için Midwestern Üniversitesi’ndeki 511 öğrencinin katılımıyla yürüttükleri 
çalışmalarında; katılım, yerel kültür ve ferahlık boyutlarının geçmiş deneyimleri canlandırdığı sonucuna ulaşmışlardır. Chandralal ve Valenzuela (2013) hatırlanabilir turizm deneyimlerinin davranışsal sonuçlarını belirlemek amacıyla sık sık seyahat eden Avustralyalı 35 turistin katılımıyla yürüttükleri çalışmalarında turistlerin keşfettikleri yeni destinasyonların hatırlanabilir turizm deneyimlerine olumlu katkı sağladığını ancak turistlerin aynı yerleri tekrar ziyaret etmek istemediklerini ancak başkalarına tavsiye etme noktasında ise olumlu bir tutum içerisinde bulunduklarını belirlemişlerdir. Sthapit (2013) hatırlanabilir turizm deneyimi ölçeğini test etmek amacıyla Rovaniemi destinasyonunu ziyaret eden 100 katılımcı ile yürüttüğü çalışmasında yerel kültür ve yenilik boyutlarının turistlerin davranışsal niyetlerini olumlu ve önemli düzeyde etkilediğini belirlemiştir. Ali ve diğerleri (2014) Malezya destinasyonlarında 600 katılımcı ile yürüttükleri çalışmalarında turist deneyiminin dört boyutunun (eğitim, eğlence, estetik ve kaçış) hatırlanabilir turizm hatıraları ve sadakati üzerinde olumlu etkileri olduğu sonucuna ulaşmışlardır.

Mahdzar ve diğerleri (2015) Malezya Mulu Milli Parkı destinasyonunun kendi özgü çekiciliklerinin turistlerin hatırlanabilir turizm deneyimine ve tekrar ziyaret niyetlerine etkilerini belirlemek amacıyla 349 katılımcı ile yürüttükleri çalışmalarında; destinasyon çekicilikleri hakkında daha yüksek algılara sahip turistlerin, hatırlanabilir turizm deneyimine sahip olma olasılıklarının da yüksek olduğu ve destinasyonu tekrar ziyaret etme niyetlerinin arttı̆̆ 1 sonucuna ulaşmışlardır. Şahin (2016) destinasyon özellikleri, hatırlanabilirlik, memnuniyet ve destinasyon deneyimi sonras1 eğilimler arasındaki ilişkileri belirlemek amacıyla İstanbul ve Antalya destinasyonlarında 1281 yabancı turistin katılımıyla gerçekleştirdiği çalışmasında; Antalya'nın ve İstanbul'un sahip oldukları destinasyon deneyimi unsurları ile turistlerin hatırlanabilirlik, memnuniyet ve destinasyon deneyimi sonrası eğilimleri arasında olumlu yönlü ilişkiler olduğunu belirlemiştir. Coudounaris ve Sthapit (2017) hatırlanabilir turizm deneyiminin faktörlerini ve ziyaretçilerin davranışsal niyetlerini ölçmek amaciyla Rovaniemi destinasyonunu ziyaret eden 314 katılımcı ile yürüttükleri çalışmalarında bilgi boyutunun turistlerin destinasyonu tekrar ziyaret etme niyetlerini ve ağızdan ağıza iletişimlerinin yönünü olumlu şekilde etkilediği sonucuna ulaşmışlardır. Akkuş (2017) kış ve spor turizmi amacıyla Erzurum'u ziyaret eden 418 Polonyalı ve İranlı turistin yaşadıkları hatırlanabilir deneyimleri değerlendirilmek ve turistlerin milletlerine göre bu deneyimlerin farklılaştığı noktaları tespit etmek amacıyla yürüttüğü çalışmasında haz (hedonizm) ve anlamlılık açısından yaşanan deneyim boyutunu Polonyalı turistlerin İranlı turistlerden daha olumlu algıladıklarını belirlemiştir.

Demir (2018) farklı kuşaklardaki insanların hatırlanabilir turizm deneyimleri algılarını ölçmek, kuşakların farklılaştıkları noktaları belirlemek, hatırlanabilir turizm deneyimlerinin tekrar ziyaret etme niyetleri ve ağızdan ağıza iletişim üzerindeki etkilerini ortaya koymak amacıyla 510 katılımcı ile yürüttüğü çalışmasında; X kuşağı için katılım, Y kuşağı için hedonizm ve ferahlık, Z kuşağı için ise ferahlık boyutlarının yüksek değerlere sahip boyutlar olarak öne çıktığını belirlemiştir. Ersoy ve Tuğal (2018) Türkiye'yi ziyaret eden Rus turistlerin destinasyon imaj algılarını ve hatırlanabilir turizm deneyimlerini ölçmek ve bu iki değişken arasındaki ilişkiyi belirlemek amacıyla Antalya destinasyonunu ziyaret eden 412 Rus turistle yürüttükleri çalışmalarında Türkiye'nin destinasyon imajının ve hatırlanabilir turizm deneyiminin olumlu olarak yorumlandığı sonucuna ulaşmışlardır.

Akşit Akış ve Kutsynska (2019) turistlerin hatırlanabilir turizm deneyimlerinin destinasyonu tekrar ziyaret etme niyetlerine ve destinasyonu tavsiye etme davranışlarına etkilerini belirlemek amacıyla 400 Ukraynalı turistin katılımıyla gerçekleştirdikleri çalışmalarında hatırlanabilir turizm deneyimi boyutlarının, tavsiye etme davranışlarını ve tekrar ziyaret niyetlerini olumlu şekilde etkilediği sonucuna ulaşmışlardır. Kırtıl (2019) Türk turistler üzerinde hatırlanabilir turizm deneyimi, 
destinasyon marka kişiliği, destinasyon aidiyeti, tatmin düzeyleri ve davranışsal niyetleri arasındaki ilişkiyi belirlemek amacıyla 452 katılımcı ile yürüttüğü çalışmasında; turistlerin bir destinasyonda hatırlanabilir deneyimler yaşamaları destinasyona yönelik sadakat hissinin oluşmasına, destinasyona bir marka kişiliği atfetmelerine ve destinasyonu tekrar ziyaret etme niyetlerine olumlu katkı sağladığı sonucuna ulaşmıştır. Kutlu (2019) ülke imajının ve destinasyon imajının hatırlanabilir turizm deneyimine etkilerini ölçmek ve destinasyonu tekrar ziyaret niyetlerine etkilerini belirlemek amacıyla Antalya'yı ziyaret eden 707 yabancı turistin katılımı ile yürüttüğü çalışmasında; hatırlanabilir turizm deneyim boyutlarından hedonizmin, yeniliğin, katılımın ve bilginin yabancı turistlerin destinasyonu tekrar ziyaret niyetlerinde olumlu etkilerinin olduğu sonucuna ulaşmıştır. Olcay ve diğerleri (2019) turistlerin tatil deneyimlerini hatırlamalarındaki önemli faktörlerin belirlenmesi amacıyla Adıyaman Üniversitesi’nde görev yapan ve daha önce tatil deneyimi yaşamış 351 akademik ve idare personel ile birlikte yürüttükleri çalışmalarında hatırlanır turizm deneyim boyutlarından hedonizmin turistlerin tatillerini hatırlamalarında en etkili faktör olduğunu, sırasıyla bilgi ve anlamlılık faktörlerinin de deneyimlerin hatırlanmasında etkilerinin olduğu sonucuna ulaşmışlardır. Chen ve diğerleri (2020) Çin'deki yerli turistlerin farklı destinasyonlara seyahatleri sonrası hatırlanabilir turizm deneyimlerini etkileyen psikolojik faktörleri belirleyerek destinasyonu tekrar ziyaret etme niyetlerini ölçmek amacıyla 413 katılımcı ile yürüttükleri çalışmalarında; hedonizm, yenilik, anlamlılık ve sosyal etkileşim boyutlarının duygu deneyimlerini olumlu yönde etkilediğini ve turistlerin yaşadıkları "eğlenceli" duyguların ise destinasyonu tavsiye etme ve tekrar ziyaret etme niyetlerini güçlendirdiği sonucuna ulaşmışlardır.

\section{Yöntem}

\section{Araştırmanın Modeli}

İlgili araştırma amacı doğrultusunda turistlerin destinasyonlarla ilgili hatırlanabilir deneyim boyutlarının destinasyona tekrar seyahat niyetlerine etkilerini belirlemek için Şekil 1'de sunulan araştırma modeli oluşturulmuştur. Araştırma modelinin oluşturulma sürecinde Kim ve diğerleri (2012) yararlanılmıştır.

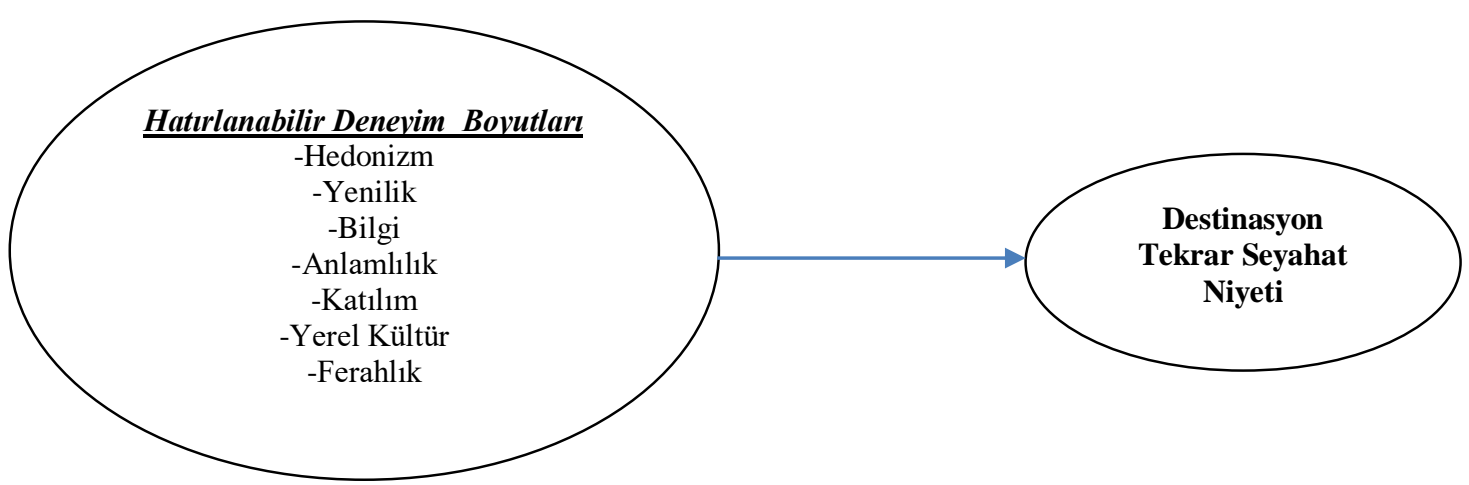

Şekil 1. Destinasyon Hatırlanabilir Deneyimleri ve Tekrar Seyahat Niyeti Modeli

\section{Araştırmanın Hipotezleri}

İlgili araştırma modelinden hareketle aşağıda verilen hipotezlerin araştırma analizleri kapsamında test edilmelerine karar verilmiştir. 
Hipotez 1. Turistlerin destinasyonlarla ilgili hatırladıkları hedonizm boyutunun düzeyi destinasyona yönelik tekrar seyahat niyetlerini etkilemektedir.

Hipotez 2. Turistlerin destinasyonlarla ilgili hatırladıkları yenilik boyutunun düzeyi destinasyona yönelik tekrar seyahat niyetlerini etkilemektedir.

Hipotez 3. Turistlerin destinasyonlarla ilgili hatırladıkları bilgi boyutunun düzeyi destinasyona yönelik tekrar seyahat niyetlerini etkilemektedir.

Hipotez 4. Turistlerin destinasyonlarla ilgili hatırladıkları anlamlılık boyutunun düzeyi destinasyona yönelik tekrar seyahat niyetlerini etkilemektedir.

Hipotez 5. Turistlerin destinasyonlarla ilgili hatırladıkları katılım boyutunun düzeyi destinasyona yönelik tekrar seyahat niyetlerini etkilemektedir.

Hipotez 6. Turistlerin destinasyonlarla ilgili hatırladıkları yerel kültür boyutunun düzeyi destinasyona yönelik tekrar seyahat niyetlerini etkilemektedir.

Hipotez 7. Turistlerin destinasyonlarla ilgili hatırladıkları ferahlık boyutunun düzeyi destinasyona yönelik tekrar seyahat niyetlerini etkilemektedir.

\section{Araştırmanın Veri Toplama Yöntemi}

Araştırmanın veri toplama sürecinde anket tekniğinden yararlanılmıştır. Yapılan bu çalışmada iki bölümden oluşan bir anket kullanılmıştır. Anketin ilk bölümü katılımcıların demografik özelliklerini belirlemeye yönelik sekiz sorudan ve bu sorulara yönelik cevaplandırıcının seçebileceği ifadelerden oluşmaktadır. Anketin ikinci bölümü ise katılımcıların destinasyon hatırlanabilir deneyim boyutlarını belirlemeye yönelik toplam 24 ve katılımcıların tekrar seyahat niyetlerini belirlemeye yönelik toplam üç 5-Kesinlikle Katıliyorum ve 1-Kesinlikle Katılmıyorum aralığında likert ifadeden oluşmaktadır. Araştırmada kullanılan destinasyon hatırlanabilir deneyim ölçeğinin ve likert tipi ifadelerin oluşturulması sürecinde Kim ve diğerlerinden (2012) ve destinasyon tekrar seyahat niyeti ölçeğinin ve likert tipi oluşturulmasında (Çetinsöz, 2011) yararlanılmıştır. $\mathrm{Bu}$ çalışmada anketin içerik geçerliğinin sağlanması, çeviri ve dil bilim konularında uzman kişilere danışılmıştır.

\section{Araştırmanın Alan Seçim Süreci}

Side destinasyonunun araştırma alanı olarak seçilmesinde; tarihi (Antik Tiyatro, Apollon ve Athena Tapınağ1, Antik Çeşme, Side Müzesi, vb.), kültürel ve doğal birçok güzelliğe ve çekiciliğe ev sahipliği yapması, bağlı bulunduğu Antalya iline gelen özellikle yerli ve yabancı turistlerin uğrak yerlerinden biri olmas1 (https://www.matso.org.tr/manavgat/side.html, 19.03.2020) ve konu kapsamında destinasyonda daha önce benzer bir çalışmanın yapılmamış olması gibi faktörler etkili olmuştur.

\section{Araştırmanın Evreni ve Örneklemi}

Araştırmanın evrenini Side destinasyonunu ziyaret eden yerli turistlerin bütünü oluşturmaktadır. Araştırma örneklemini ise veri toplama süresi içerisinde ilgili destinasyonu ziyaret eden ve ulaşılabilen yerli turistler oluşturmaktadır. Ancak bu araştırmanın veri toplama süreci içerisinde ve bir önceki yılın aynı döneminde (1 Mayıs-30 Eylül 2019) ilgili destinasyonu tam olarak kaç kişinin ziyaret ettiği ve bu ziyaretçilerin ne kadarının yerli turistlerden oluştuğu tam, güvenilir ve resmi istatistiklerle tespit edilememiştir. $\mathrm{Bu}$ sebeple araştırma örneklemini hesaplamak için hedef kitledeki birey sayısının bilinmediğinden hareketle; " $\mathrm{n}=\mathrm{t}^{2} \mathrm{pq} / \mathrm{d}^{2}$ formülden" yararlanılmıştır (Yazıcıoğlu ve Erdoğan, 2007, 70). Formül çerçevesinde ilgili değerleri yerine koyarak araştırma 
örneklem sayısı; $n=(1,96)^{2}(0,5) \times(0,5) /(0,05)^{2} ; n=0,9535 / 0,0025 ; n=384$ olarak belirlenmiştir. Hesaplanan örneklem büyüklügüne ulaşmak için araştırma katılımcılarının belirlenmesi sürecinde zaman ve maliyet avantajı, erişim kolaylığı ve eldeki mevcut veya gönüllü bireylere uygulanması avantajları nedeniyle olasılığa dayalı olmayan örnekleme yöntemlerinden kolayda örnekleme yönteminden yararlanılmıştır (Erkuş, 2011, 106). Araştırmaya yönelik verilerin elde edilmesi için yerli turistlerle yüz yüze iletişim kurularak 500 anket formu ulaştırılmıştır. Ancak geri dönüş sağlanan anketlerden 28 tanesi her soruya aynı cevabın kodlanması ve 16 anket ise cevap kodlamalarının \%50'sinden fazlasının boş bırakılmasından dolayı değerlendirme dışında bırakılmıştır. Araştırmanın değerlendirme kısmına 456 anket dâhil edilmiştir ve anketlerin geri dönüş oranı \%91 olarak gerçekleşmiştir.

\section{Araştırmanın Analizleri}

Araştırma sonucunda anketlerden elde edilen veriler bilgisayara kaydedilerek veri seti oluşturulmuştur. İlgili veri seti SPSS istatistiki veri programında analize tabi tutulmuştur. Araştırma anketinden elde edilen yerli turistlerin demografik değişkenlerine ilişkin veriler yüzde ve sıklık değerleriyle analiz edilmiştir. S1klık analizinden sonra ölçekteki likert tipi ifadelerin güvenirliği analiz edilmiştir. Değişkenlerin güvenirlik analizinde Cronbach's Alpha katsayısından yararlanılmıştır. Güvenirlik analizinden sonra ölçeğin yapı geçerliğini test etmek amacıyla açıklayıcı faktör analizi yapılmıştır. Araştırmada ayrıca ilgili araştırma boyutları regresyon analizine dâhil edilmiştir.

\section{Bulgular}

\section{Katılımcılara İlişkin Bulgular}

Araştırmanın örneklem özelliklerine ilişkin genel bir değerlendirmenin yapılabilmesi için uygulanan sıklık analizi (Tablo 1) sonuçlarına göre katılımcıların çoğunluğu erkek (\%64), 25-60 yaş aralı̆̆ında (\%47), lisans düzeyinde eğitime sahip (\%46), özel sektör çalışanı (\%27) ve öğrenci (\%27), $5001 \mathrm{TL}$ ve üzerinde aylı gelire sahip (\%42), destinasyonu birden fazla kez destinasyonu ziyaret eden (\%71), önceki deneyimlerinden çok yüksek düzeyde etkilenen (\%75) ve destinasyona tekrar seyahat etme niyetinde olan (\%83) turistlerden oluşmaktadırlar.

\section{Güvenirlik Analizi Bulguları}

Bu araştırmada 1 Mayıs-15 Mayıs 2019 döneminde 84 yerli turistin katılımı ile uygulanan pilot testin sonucunda kullanılan ölçeğin Cronbah's Alpha katsayısı ,901 olarak bulunmuştur. Elde edilen katsayı oranları ölçeğin güvenilir olduğuna işaret etmektedir.

\section{Faktör Analizi Bulguları}

Bu çalışmada açıklayıcı faktör analizinden yararlanılmıştır. Açıklayıcı faktör analizi sonucunda; sig. $(\mathrm{p})=0,000$ anlamlılık düzeyinde KMO değeri ,888 olarak belirlenmiştir. Ayrıca Barlett's Testi sonucu 3346,914 olarak tespit edilmiştir. Bu oranın düzeyi ve elde edilen KMO değeri örneklem büyüklüğünün faktör analizi için yeterli ve uygun olduğunu göstermektedir. Çalışmada hem faktör yükleri açısından küçük hem de katsayısı küçük ifadeler (communalities) değerlendirme dışı bırakılarak faktör analizinin geçerliğinin arttırılması amaçlanmıştır. Yapılan bu iki işlem sonucunda ölçekte yer alan 24 ifadeden iki tanesinin "Destinasyondaki ilk tatil deneyimimdi", 
"Destinasyondaki tatilimde hissettiğim özgürlük heyecan vericiydi" ölçekten çıkartılmasına karar verilmiştir. Faktör analizi sonucunda özdeğeri birden büyük 22 ifadeden oluşan yedi boyut belirlenmiştir. $\mathrm{Bu}$ boyutlar toplam varyansın \%71,231'ini açıklamaktadır. Araştırmada elde edilen varyans oranı alınyazına göre kabul edilebilir bir düzeydedir (Altunışık ve diğerleri, 2007, 347). Araştırmada faktör analizine ilişkin olarak Kim ve diğerleri (2012) çalışması referans alınmıştır ve ilgili boyutlar; Hedonizm (HDN), Yenilik (YNL), Ferahlık (FRH), Anlamlılık (ANL), Katılım (KTL), Yerel Kültür (YK) ve Bilgi (BLG) olarak adlandırılmıştır. Ayrıca yerli turistlerin araştırma ölçeği boyutlarını değerlendirmelerine yönelik sonuçlara göre (Tablo 2); bilgi $(\tilde{\mathrm{x}}=4,58)$, ferahlık $(\tilde{\mathrm{X}}=4,56)$, kat1lım $(\tilde{\mathrm{x}}=4,54)$, yenilik $(\tilde{\mathrm{X}}=4,51)$, bilgi $(\tilde{\mathrm{x}}=4,48)$, hedonizm $(\tilde{\mathrm{x}}=4,44)$ ve yerel kültür $(\tilde{\mathrm{X}}=4,44)$ boyutlarına katılımları yüksek ve olumlu düzeydedir.

Tablo 1. Araştırmaya Katılan Turistlerin Demografik Özelliklerine Göre Dağılımları (N=456)

\begin{tabular}{|c|c|c|c|}
\hline Demografik Özellikler & & Sayı (n) & Yüzde (\%) \\
\hline \multirow[t]{2}{*}{ Cinsiyet } & Kadın & 164 & 36,0 \\
\hline & Erkek & 292 & 64,0 \\
\hline \multirow[t]{3}{*}{ Yaş } & $15-24$ yaş aralığ & 105 & 23,0 \\
\hline & $25-60$ yaş aralığ & 215 & 47,1 \\
\hline & 61 yaş ve üzeri & 136 & 29,9 \\
\hline \multirow[t]{4}{*}{ Eğitim Düzeyi } & Lise ve Altı & 42 & 9,2 \\
\hline & Önlisans & 66 & 14,5 \\
\hline & Lisans & 210 & 46,0 \\
\hline & Lisansüstü & 138 & 30,3 \\
\hline \multirow[t]{5}{*}{ Meslek } & Öğrenci & 124 & 27,2 \\
\hline & Özel sektör çalışanı & 126 & 27,6 \\
\hline & Kendi işini yapan & 103 & 22,6 \\
\hline & Kamu çalışanı & 56 & 12,3 \\
\hline & Emekli & 47 & 10,3 \\
\hline \multirow[t]{3}{*}{ Aylık Gelir } & 2500 TL ve daha az & 105 & 23,0 \\
\hline & 2501 TL-5000 TL aras1 & 160 & 35,1 \\
\hline & 5001 TL ve üzeri & 191 & 41,9 \\
\hline \multirow{2}{*}{$\begin{array}{l}\text { Destinasyonu Ziyaret } \\
\text { Sayısı }\end{array}$} & İlk ziyaret & 131 & 28,7 \\
\hline & Birden fazla ziyaret & 325 & 71,3 \\
\hline \multirow{2}{*}{$\begin{array}{l}\text { Deneyimlerinden } \\
\text { Etkilenme Düzeyi }\end{array}$} & Çok Yüksek & 341 & 74,8 \\
\hline & Yüksek & 115 & 25,2 \\
\hline \multirow{2}{*}{$\begin{array}{l}\text { Destinasyonu Tekrar } \\
\text { Seyahat Niyeti }\end{array}$} & Evet & 376 & 82,5 \\
\hline & Hayır & 80 & 17,5 \\
\hline \multicolumn{2}{|l|}{ Toplam } & 456 & 100 \\
\hline
\end{tabular}

Tablo 2. Araştırma Ölçeğine İlişkin Faktör Analizi Sonuçları ( $n=456)$

\begin{tabular}{|l|c|c|c|c|}
\hline Boyutlar & Özdeğerler & Alpha & Açılanan Vary. & Ort. \\
\hline Hedonizm & $\mathbf{4 . 2 1 4}$ & $\mathbf{8 8 1}$ & $\mathbf{1 4 , 3 4 1}$ & $\mathbf{4 , 4 4}$ \\
\hline Destinasyondaki yeni deneyimlerden haz duyarım. &, 766 & & & \\
\hline Destinasyondaki turistik aktivitelerden keyif alırım. &, 754 & & & \\
\hline $\begin{array}{l}\text { Destinasyondaki tatil deneyimimden gerçekten } \\
\text { heyecan duyarım. }\end{array}$ &, 732 & & & \\
\hline $\begin{array}{l}\text { Destinasyondaki tatil deneyimimden heyecan } \\
\text { duyarım. }\end{array}$ &, 726 & & & \\
\hline Yenilik & $\mathbf{3 , 6 7 4}$ & $\mathbf{8 6 6}$ & $\mathbf{1 2 , 5 6 7}$ & $\mathbf{4 , 5 1}$ \\
\hline
\end{tabular}




\begin{tabular}{|c|c|c|c|c|}
\hline Destinasyondaki tatil deneyimim eşsizdi. & ,788 & & & \\
\hline $\begin{array}{l}\text { Destinasyondaki tatil deneyimim öncekilerden } \\
\text { farkliyd. }\end{array}$ & ,782 & & & \\
\hline $\begin{array}{llll}\begin{array}{l}\text { Destinasyondaki } \\
\text { deneyimledim. }\end{array} & \text { tatilimde } & \text { yeni } & \text { şeyler } \\
\end{array}$ & ,777 & & & \\
\hline Ferahlık & $\mathbf{3 , 5 8 8}$ & ,851 & $\mathbf{1 1 , 1 1 4}$ & 4,56 \\
\hline Destinasyondaki tatilimde kendimi özgür hissettim. & ,744 & & & \\
\hline $\begin{array}{l}\begin{array}{l}\text { Destinasyondaki tatilimde } \\
\text { hissettim. }\end{array} \\
\end{array}$ & ,731 & & & \\
\hline $\begin{array}{l}\text { Destinasyondaki tatilimde kendimi canlanmış } \\
\text { hissettim. }\end{array}$ & ,718 & & & \\
\hline Anlamlılık & 2,156 & ,895 & 8,655 & $\mathbf{4 , 4 4}$ \\
\hline Destinasyondaki tatilimde anlamlı şeyler yaptım. & ,716 & & & \\
\hline Destinasyondaki tatilimde önemli şeyler yaptım. & ,706 & & & \\
\hline $\begin{array}{l}\text { Destinasyondaki tatilimde kendim hakkımda yeni } \\
\text { şeyler öğrendim. }\end{array}$ & ,696 & & & \\
\hline Katılım & 2,998 &, $\mathbf{8 2 3}$ & 9,234 & 4,54 \\
\hline $\begin{array}{l}\text { Gerçekten gitmek istediğim bir destinasyona tatile } \\
\text { gittim. }\end{array}$ & ,726 & & & \\
\hline $\begin{array}{l}\text { Gerçekten yapmak istediğim turistik aktiviteleri } \\
\text { yapmaktan keyif aldım. }\end{array}$ & ,711 & & & \\
\hline $\begin{array}{l}\text { Gerçekten ilgilendiğim turistik } \\
\text { katıldım. }\end{array}$ & ,703 & & & \\
\hline Yerel Kültür & 2,447 & ,856 & 8,188 & $\mathbf{4 , 5 8}$ \\
\hline 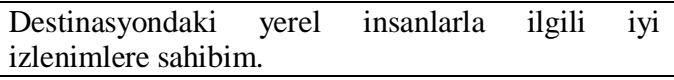 & ,734 & & & \\
\hline $\begin{array}{lll}\begin{array}{l}\text { Destinasyondaki yerel } \\
\text { arkadaşliklar kurdum. }\end{array} & \text { insanlarla } & \text { yakın } \\
\end{array}$ & ,719 & & & \\
\hline $\begin{array}{l}\begin{array}{l}\text { Destinasyondaki yerel insanlar } \\
\text { canlısıdi. }\end{array} \\
\text { çok }\end{array}$ & ,702 & & & \\
\hline Bilgi & $\mathbf{1 , 3 4 5}$ & ,908 & 7,132 & 4,48 \\
\hline Tatil deneyimimden keşif hissi yaşadım. & ,724 & & & \\
\hline Tatil deneyimimden bilgilendiğim hissini yaşadım. & ,717 & & & \\
\hline $\begin{array}{l}\text { Tatil deneyimimden yeni kültür öğrenme hissi } \\
\text { yaşadım. }\end{array}$ & ,709 & & & \\
\hline Tekrar Seyahat Niyeti & $\mathbf{1 , 4 5 9}$ & ,896 & 8,132 & 4,56 \\
\hline Tatil için tekrar Side destinasyonuna gelirim. & ,741 & & & \\
\hline $\begin{array}{l}\text { Side destinasyonu tekrar tatile gelmeye değer bir } \\
\text { yerdir. }\end{array}$ & ,734 & & & \\
\hline $\begin{array}{l}\text { Sosyal çevreme Side destinasyonuna gitmeleri için } \\
\text { tavsiyede bulunacağım. }\end{array}$ & ,721 & & & \\
\hline
\end{tabular}

Side destinasyonunu ziyaret eden yerli turistlerin tekrar seyahat niyetlerini ölçmek amacıyla yapılan sıklık analizi sonuçlarına göre (Tablo 3); katılımcıların destinasyona tekrar seyahat niyetlerinin ve destinasyonu tavsiye kararlarının olumlu ve yüksek olduğunu söylemek mümkündür. 
Tablo 3. Katılımcıların Destinasyonu Tekrar Seyahat Niyetine İlişkin Dağılımları $(\mathrm{N}=456)$

\begin{tabular}{|l|c|c|c|c|}
\hline Tekrar Seyahat Niyeti & Sayı (n) & Ort. & Std. Sap. & Alpha \\
\hline Tatil için tekrar Side destinasyonuna gelirim. & & 4,56 & 1,19 & \multirow{2}{*}{, 901} \\
\cline { 1 - 1 } $\begin{array}{l}\text { Side destinasyonu tekrar tatile gelmeye değer bir } \\
\text { yerdir. }\end{array}$ & \multirow{456}{4561}{} & 1,17 & \\
\cline { 1 - 2 } $\begin{array}{l}\text { Sosyal çevreme Side destinasyonuna gitmeleri için } \\
\text { tavsiyede bulunacağım. }\end{array}$ & 4,46 & 1,09 & \\
\hline
\end{tabular}

\section{Regresyon Analizi Bulguları}

Araştırma hipotezlerinin test edilmesi amacıyla yapılan regresyon analizi sonuçlarına göre (Tablo 4) turistlerin destinasyon seyahat niyetlerini açıklayan DHD boyutlarını belirlemeye yönelik regresyon modelinin bir bütün olarak anlamlı olduğu görülmektedir $(F=41,113 ; \mathrm{p}<0,05)$. Beta değerlerinin anlamlılık düzeyleri incelendiğinde ise tüm DHD boyutlarının turistlerin destinasyon seyahat niyetlerini yüksek ve olumlu düzeyde etkilediklerini söylemek mümkündür. İlgili sonuçlar çerçevesinde tüm araştırma hipotezleri kabul edilmiştir.

Tablo 4. DHD-DSN Boyutlarına İlişkin Regresyon Analizi Sonuçları

\begin{tabular}{|c|c|c|c|c|c|c|c|c|}
\hline & Boyutlar & Beta & $t$ & $p$ & $r^{2}$ & $F$ & $V I F$ & Hipotezler \\
\hline \multirow{7}{*}{ DSN } & HDN & ,554 & 3,546 &, 000 & ,224 & \multirow[b]{4}{*}{41,113} & 1,655 & H 1 Kabul \\
\hline & YNL & ,532 & 3,187 & ,000 & ,203 & & 1,741 & H 2 Kabul \\
\hline & FRH &, 448 & 4,678 &, 000 & ,136 & & 1,456 & H 3 Kabul \\
\hline & ANL & ,434 & 4,167 & ,000 & ,198 & & 1,149 & H4 Kabul \\
\hline & KTL &, 345 & 2,986 &, 000 &, 186 & & 1,245 & H5 Kabul \\
\hline & YK & ,389 & 2,438 &, 000 &, 124 & & 1,673 & H6 Kabul \\
\hline & BLG &, 428 & 3,129 &, 000 &, 135 & & 1,108 & H7 Kabul \\
\hline
\end{tabular}

\section{Tartışma, Sonuç ve Öneriler}

$\mathrm{Bu}$ çalışmada Side destinasyonunu ziyaret eden yerli turistlerin destinasyon seyahat niyetlerine destinasyon hatırlanabilir deneyim boyutlarının etkilerinin belirlenmesi amaçlanmaktadır. $\mathrm{Bu}$ kapsamda yapılan araştırma analizlerinin sonuçlarına göre katılımcıların çoğunluğu erkek, 25-60 yaş aralığında, lisans düzeyinde eğitime sahip, özel sektör çalışanı ve öğrenci, $5001 \mathrm{TL}$ ve üzerinde aylık gelire sahip, destinasyonu birden fazla kez destinasyonu ziyaret eden, önceki deneyimlerinden çok yüksek düzeyde etkilenen ve destinasyona tekrar seyahat etme niyetinde olan turistlerden oluşmaktadırlar. Araştırma analizlerinin sonuçlarına göre katılımcıların destinasyon hatırlanabilir deneyim boyutlarının tümünün yüksek ve olumlu düzeyde destinasyonu tekrar seyahat niyetlerine etki ettikleri sonucuna ulaşı1mıştır.

Ayrıca ilgili araştırma boyutlarının tümüne turistlerin katılımları yüksek ve olumlu düzeyde gerçekleşmiştir. Yerli turistlerin ilgili destinasyona yönelik seyahat niyetleri ve önceki seyahat deneyimlerinden etkilenme düzeyleri ise oldukça yüksektir. Yapılan bu araştırmanın ilgili alanyazına, destinasyon yönetim örgütlerine ve sonraki çalışmalara elde edilen uygulama sonuçları itibariyle katkı sağlayacağı düşünülmektedir. Çünkü ilgili konu başlığında Türkçe alanyazında özellikle uygulama temelli sonuç eksikliği görülmüştür ve Side destinasyonunda konu kapsamında herhangi bir çalışmaya ulaşılamamıştır. Ayrıca destinasyon hatırlanabilir deneyimi konularında Türkçe ve yabancı alanyazında çeşitli çalışmalar yürütülmüşse de destinasyon seyahat niyeti ile 
ilişkilendiren çalışmalar yok denecek kadar azdır. Diğer yandan araştırma sonuçlarının destinasyonların planlama ve pazarlama çalışmalarında yarar sağlayacağı düşünülmektedir. Çünkü destinasyonlarda turistlerin turistik ürünlerle, hizmetlerle ve destinasyonun bütünüyle ilgili hatırladıkları deneyimlerinin destinasyonu tekrar seçim süreçlerine olumlu veya olumsuz olarak doğrudan etki ettiği söylenebilir.

Destinasyonlar arasında ulusal ve uluslararası yaşanan yoğun rekabet, turistlerin alternatif bilgi edinme araçlarının ve kaynaklarının sayılarındaki artış, küresel ölçekte destinasyonlara erişimin ve ulaşımın kolaylaşması, vb. destinasyonlar arasında turistik talebi kendilerine yönlendirme noktasında kıyasıya bir mücadeleyi de beraberinde getirmektedir. Bu noktada başarı sağlamak ve turistik talebi kendilerine çekmek isteyen destinasyonlar turistlerde olumlu hatırlanacak deneyimleri edinmelerini sağlamak adına faaliyetlerini yürütmeleri oldukça önem kazanmaktadır. Turistlerin destinasyona yönelik bilgi arama sürecinden tatil sonrası değerlendirme aşamasına kadar sürdürülecek sağlıklı, yapıcı ve sürekli bir iletişim ve hizmet süreci turistlerin sonraki satın alma ve karar süreçlerine olumlu katkılar sağlayacaktır.

Araştırma maddi kaynaklar ve zaman sınırlığından dolayı örneklem büyüklüğü alanyazında kabul edilen sınırlar içerisinde olmakla birlikte farklı milletlerden katılımcılara uygulanamamıştır. Gelecekteki çalışmalarda araştırmaya dâhil edilecek turistlerin milletlerinin çeşitliliğinin arttırılması araştırma sonuçlarının genellenmesi açısından olumlu katkılar sağlayacaktır.

\section{Kaynakça}

Ali, F., Hussain, K. \& Ragavan A. N. (2014). Memorable customer experience: Examining the effects of customers experience on memories and loyalty in malaysian resort hotels, Procedia Social and Behavioral Sciences 144, 5th Asia Euro Conference, Selangor, Malaysia, (19-21 May).

Altunışık, R., Çoşkun, R., Bayraktaroğlu, S. \& Yıldırım, E. (2007). Sosyal bilimlerde araştırma yöntemleri SPSS uygulamalı (geliş̧tirilmiş beşinci baskı). Sakarya: Sakarya Yayıncılık.

Akkuş, G. (2017). Kış turizmi destinasyonunda yaşanan unutulmaz turizm deneyimleri: kültürlerarası karşılaştırma. Seyahat ve Otel İ̧sletmeciliği Dergisi, 14(3), 223-236.

Aşık Akşit, N. \& Kutsynska, V. M. (2019). Unutulmaz turizm deneyimlerinin tekrar ziyaret niyeti ve tavsiye etme davranışına etkisi: Ukraynalı turistler üzerinde bir araştırma. Uluslararası Sosyal Araştırmalar Dergisi, 12(68), 1007-1017.

Bowen, D. \& Clarke, J. (2009). Contemporary tourist behavior: yourself and others and tourists. UK: CABI.

Chandralal, L. \& Valenzuela, R-F. (2013). Exploring memorable tourism experiences: antecedents and behavioural outcomes, journal of economics. Business and Management, 1(2), 177-181.

Chen, H. \& Rahman, I. (2018). Cultural tourism: an analysis of engagement, cultural contact, memorable tourism experience and destination loyalty. Tourism Management Perspectives, 26, 153-163.

Chen, X., Cheng, F. Z. \& Kim, B. G. (2020). Make it memorable: tourism experience, fun, recommendation and revisit intentions of chinese outbound tourists. Sustainability, 12(5), 1-24.

Cornelisse, M. (2014). Memorable tourist experiences in authentic Vicos, Peru. Journal of Tourism Consumption and Practice, 6(1), 104-127.

Coudounaris, D. N. \& Sthapit, E. (2017). Antecedents of memorable tourism experience related to behavioral intentions. Psychology and Marketing, 34(12), 1084-109. 
Çetinsöz, C. B. (2011). Uluslararası seyahatlerde turistlerin çekim yerinde alglladıları risklerin tekrar ziyaret etme niyetlerine etkileri: Alanya ilçesine yönelik bir araştırma. Yayınlanmamış doktora tezi, Adnan Menderes Üniversitesi Sosyal Bilimler Enstitüsü.

Demir, S. (2018). Kuşaklar açısından unutulmaz turizm deneyimleri algısının satın alma sonrası davranışlar üzerindeki etkisi. Yayınlanmamış yüksek lisans tezi, Trakya Üniversitesi Sosyal Bilimler Enstitüsü.

Demir, S. \& Demirel Ülker, E. (2019). Bir deneyimi unutulmaz kılan unsurlar nedir? unutulmaz turizm deneyimi üzerine kavramsal bir değerlendirme. Trakya Üniversitesi Sosyal Bilimler Dergisi, 21(2), 661-682.

Duarte, P. (2012). Tourist experience: contemporary perspectives. Journal of Heritage Tourism, 7(2), 187188.

Dunman, T. \& Mattila, A. S. (2005). The role of affective factors on perceived cruise vacation value. Tourism Management, 26, 311-332.

Erkuş, A. (2011). Davranış bilimleri için bilimsel araştırma süreci (güncellenmiş üçüncü baskl). Ankara: Seçkin Yayıncılık.

Ersoy, M. \& Tuğal, F. N. (2018). Türkiye'yi ziyaret eden Rus turistlerin destinasyon imaj algılamaları ve hatırlanabilir turizm deneyimleri üzerine bir araştırma. Artıbilim: Adana Bilim ve Teknoloji Üniversitesi Sosyal Bilimler Dergisi, 1(2), 64-78.

Han, H., Back, K. J. \& Barrett, B. (2009). Influencing factors on restaurant customers' revisit intention: the roles of emotions and switching barriers. International Journal of Hospitality Management, 28(4), 563-572.

Hoch, S. J. \& Deighton, J. (1989). Managing what consumers learn from experience. Journal of Marketing, $53(4), 1-20$.

Kerstetter, D. \& Cho, M. H. (2004). Tourists' information search behavior: the role of prior knowledge and perceived credibility. Annals of Tourism Research, 31(4), 961-985.

Kırtıl, G. İ. (2019). Unutulmaz turizm deneyimi, destinasyon marka kişiliği, destinasyon aidiyeti, tatmin ve davranışsal niyet ilişkisi: Antalya örneği. Yayınlanmamış yüksek lisans tezi, Akdeniz Üniversitesi Sosyal Bilimler Enstitüsü.

Kim, J. H. (2010). Determining the factors affecting the memorable nature of travel experiences. Journal of Travel and Tourism Marketing, 27(8), 780-796.

Kim, J.-H., Ritchie, J. R. B. \& Vincent, V. W. S. (2010). The effect of memorable experience on behavioral intentions in tourism: a structural equation modeling approach. Tourism Analysis, 15(6), 637-648.

Kim, J. H. (2014). The antecedents of memorable tourism experiences: the development of a scale to measure the destination attributes associated with memorable experiences. Tourism Management, 44(10), 3445 .

Kim, J-H., Ritchie, J. R. B. \& McCormick, B. (2012). Development of a scale to measure memorable tourism experiences. Journal of Travel Research 51(12), 12-25.

Kutlu, D. (2019). Ülke imajı ve destinasyon imajının hatırlanabilir turizm deneyimi yaratmadaki rolünün belirlenmesi üzerine bir araştırma. Yayınlanmamış doktora tezi, Karadeniz Teknik Üniversitesi Sosyal Bilimler Enstitüsü.

Mahdzar, M., Shuib, A., Ramachandran, S. \& Herman, M. S. (2015). The role of destination attributes and memorable tourism experience in understanding tourist revisit intentions. American-Eurasian 
Journal of Agricultural and Environmental Sciences (Tourism and Environment, Social and Management Sciences), 15(1), 32-39.

Marschall, S. (2012). Tourism and memory. Annals of Tourism Research, 39(4), 2216-2219.

Olcay, A., Karacıl, G. \& Sürme, M. (2019). Hatırlanır turizm deneyimini etkileyen faktörlerin belirlenmesine yönelik bir araştırma. Journal of Tourism and Gastronomy Studies, 7(4), 2824-2838.

Ooi, C-S. (2003). Crafting tourism experiences: managing the attention product, 12th Nordic Symposium on Tourism And Hospitality Research, Stavanger, Norway, (2-5 October).

Selstad, L. (2007). The social anthropology of the tourist experience. exploring the middle role. Scandinavian Journal of Tourism and Hospitality, 7(1), 19-33.

Side Hakkında. (2020). Erişildi Mart 19, 2020, Manavgat Sanayi ve Ticaret Odası, https://www.matso.org.tr/manavgat/side.html

Sthapit, E. (2013). Tourists' perceptions of memorable experiences: testing the memorable tourism experience scale (mtes) among tourists to Rovaniemi, Lapland. Unpublished master thesis, University of Lapland Faculty of Social Sciences.

Şahin, İ. (2016). Hatırlanabilir turizm deneyimlerini etkileyen destinasyon özelliklerinin belirlenmesi: antalya ve istanbul destinasyonları üzerinde karşılaş̧ırmalı bir araştırma. Yayınlanmamış yüksek lisans tezi, Akdeniz Üniversitesi Sosyal Bilimler Enstitüsü.

Uysal, M., Perdue, R. \& Sirgy. M.J. (2012). Handbook of tourism and quality-of-life research: enhancing the lives of tourists and residents of host communities. Dordrecht: Springer.

Yazıcıoğlu, Y. \& Erdoğan, S. (2007). SPSS uygulamalı bilimsel araştırma yöntemleri (genişletilmiş ikinci baskl). Ankara: Detay Yayıncilık.

Zhang, H., Wu, Y. \& Buhalis, D. (2017). A model of perceived image, memorable tourism experiences and revisit intention. Journal of Destination Marketing and Management, 8(6), 326-336. 